\title{
A New Library for a New College
}

By KENNETH T. SLACK

$\mathrm{O}^{-}$ July 21, 1954, the final decision was made by the leadership of the Church of Jesus Christ of Latter-day Saints (Mormon Church) to establish a junior college in Hawaii. Some thirtythree years of talking about such an institution had preceded the decision which was long past due in the light of L.D.S. educational philosophy and the numbers of L.D.S. church members in the Islands.

An essential part of the religious belief of the L.D.S. people is their concept of education. Their doctrine is full of such dogma as "Man cannot be saved in ignorance"; "The glory of God is intelligence"; "Man is saved only so fast as he gains knowledge." The consequence of such an emphasis on education has resulted in high educational achievement in states such as Utah and Idaho, where the population is predominantly L.D.S. ${ }^{1}$

Dr. Reuben D. Law was appointed president of the new institution. His first activity was to head a committee to make a survey of the educational needs of the Islands. It was immediately apparent to this committee that Hawaii could support another four-year institution though the Church originally intended to establish a junior college. This fact resulted in the acceptance of the principal that all planning for buildings, equipment, and facilities be on the scale of adequacy for a four-year institution.

When the librarian was appointed in June, 1955, the preliminary planning for the library was already accomplished.

\footnotetext{
1 Ray L. DeBoer, "A Historical Study of Mormon Education and the Influence of its Philosophy on Public Education in Utah." (Ph.D. dissertation, University of Denver, 1951); Raymond $\dot{M}$. Hughes and William $\mathrm{H}$. Lancelot, Education-America's Magic, (Ames: Iowa State College Press, 1946), pp. 40-41; Roy C. Woods "Where Does Your State Rank?" American School Board Journal, CX (1945), 21-24.
}

Mr. Slack is Librarian, The Church College of Hawaii, Laie.

The plans called for a library of 9,800 square feet of floor space, including only one large reading room, a stack tower, librarian's office, workroom, a classroom, and two small rooms to house audiovisual facilities. The stacks were to be closed, and no area was provided for current or bound periodical shelving. The librarian's first official act was to call attention to the inadequacy of these plans for the library needs of a four-year institution. Built to these original plans it would have housed only some fifteen thousand to eighteen thousand volumes, which may have satisfied the needs of a small junior college but would have been totally inadequate to the needs of a fouryear degree-conferring institution.

The governing board of the new Church College of Hawaii at that time was made up of some of the prominent businessmen of the Islands who were also members of the L.D.S. faith. They had no previous experience with policy decisions regarding higher education, and they had to be shown that the original plans were inadequate. The librarian found the statistics published by ACRL very valuable in meeting this problem. The annual January issue of $C R L$ showing average size of collections, size of book budgets, and size of staff for institutions of our contemplated enrollment provided ammunition that found its mark in the thinking of the board members.

Also, the ALA scorecard for evaluating degree-conferring four-year institutions 


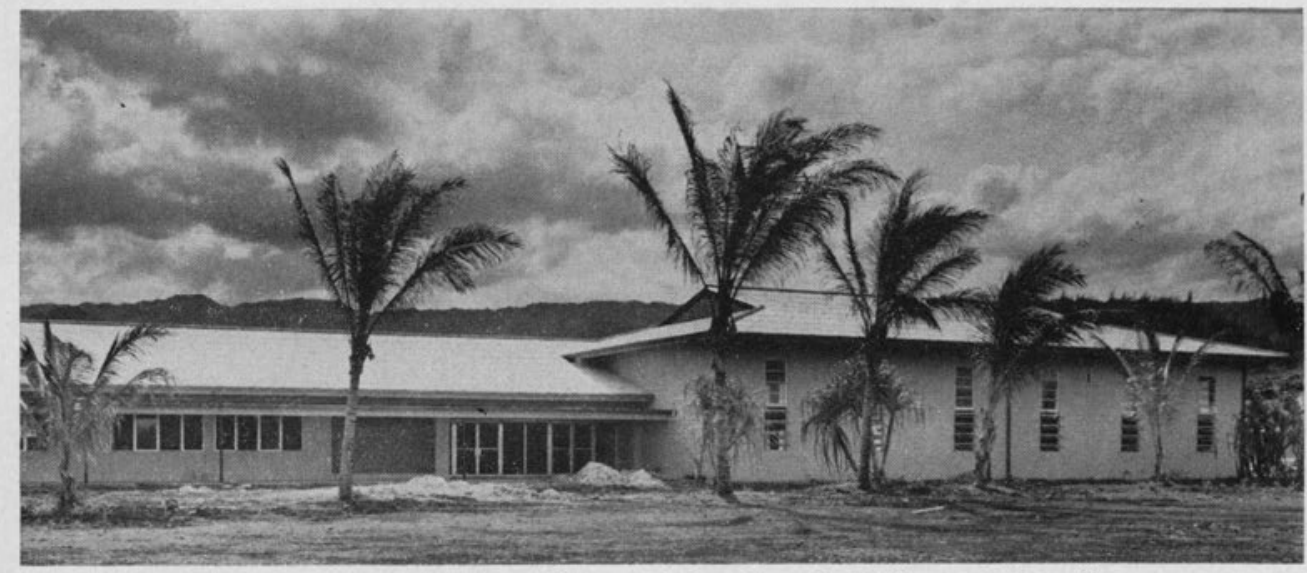

Exterior View of the Library of the Church College of Hawaii

proved invaluable, because the Western College Association uses this scorecard in its schedules for accrediting college libraries. According to the scorecard, the minimum requirement for a four-year institution was at that time to be in no case less than forty thousand volumes. And since it was the full intention of the Church College of Hawaii to meet the Western College Association standards in every phase of their effort, this fact alone was sufficient evidence to cause the board to decide to build a much larger library.

How much larger the library needed to be was the next matter of interest to them. The ALA monograph edited by Hoyt R. Galvin, Planning a Library Building-The Major Steps, fortunately gave the size of every college library built in the United States during the years 1949-1954. Figuring from this, it was found that the average library for colleges of our anticipated student enrollment (one thousand students) was fifteen thousand square feet. Only one small college in the South had erected a library as small as the original Church College plans. The board responded to this information by making the decision to build a library of 18,500 square feet which was nearly double the size of the original plans.

Of course, the librarian rejoiced in the opportunity to start from scratch in preparing minimum standards for the architect. The general conditions anticipated for the college library were explained and the specifications for the various areas were rewritten in detail.

Preparation of a program for the architect was almost an entirely new experience for the librarian. He had served on a building committee in the Denver Public School system with Elsa Berner in establishing the minimum standards for six new junior high school libraries. There, the method had been to visit several new and old libraries in the city to learn the best architectural features of each of them and also to discover the architectural errors so that the best features could be included in the standards and the errors be avoided. Such guides as the ALA publication, Dear $\mathrm{Mr}$. Architect, and the California school building standards were referred to in this instance. His two previous years had been spent in the new Eastern Oregon College Library and acquaintance with their program was a help.

Letters were written to the librarians of each of the new libraries reported in the ALA publication, Planning a Library Building, requesting a look at their plans and their building programs. Severál of these librarians obliged by lending their 
plans and programs. The program for Goucher College Library in Maryland was particularly helpful.

The final plans called for a library costing some $\$ 251,800$, unique in this matter because it was constructed with voluntary missionary labor. Thus, the money appropriated was devoted entirely to costs for building material and furnishing. It was estimated that some fiftyfive thousand man hours of donated missionary labor were used in its construction.

The library now finished, but not fully furnished, will seat 284 students at one time. Shelving will eventually be provided for some sixty thousand volumes. Presently only sufficient shelving is available for twenty thousand volumes. The prevalence of rust and termites in the Hawaiian climate has caused postponement of acquiring full furnishings until they are needed. Open stacks are in all areas except the treasure room.

The rooms include: periodical reading room designated by free standing periodical stacks the outside of which shelve the reference collection, general reference reading room, reading areas in the main floor of the stack room and the mezzanine stack room, an audio-visual workroom and classroom, a record listening room containing units with headphones, a film storage room, a workroom for technical processes, and a librarian's office.

Concentrated on the first floor are the services and materials used most extensively by students and teachers. The reserve book stacks are located behind the circulation counter. The periodical indexes are located in the reading reference area midway between the current periodicals and the bound periodicals. Eventually, the outdoor reading lanai will be furnished with informal comfortable furniture and it will be used as a loud-study area. All traffic leaving the building must pass the circulation counter.
Some of the guiding principles laid down for the architect were, first of all, the idea that there must be juxtaposition of book space and reading space. Reading spaces are relatively small, rather than the monumental study halls found in libraries of the past. Even though we are not ever to be a graduate institution, we follow this principle in providing, in addition to the small reading areas, semiprivate cubicles such as book carrels.

Quite a number of the people who have visited the library wondered how much more the building would have cost had we paid for the labor. This, of course, could only be estimated. Perhaps the donated fifty-five thousand man hours were worth $\$ 125,000$.

The volunteer missionary labor system employed in construction is an idea developed by the president of our church, David O. McKay. It has been used extensively throughout the Pacific area to build schools and chapels. It is a common aspiration among the L.D.S. people to fulfill a proselyting mission of two years. Most of us do it at about age twenty. Among the skilled craftsmen, the desire exists, but many of them feel they lack articulateness to preach the gospel. So they are happy to make their contribution, not by preaching, but by leading the Polynesian natives in a far-flung demonstration of the American "do-it-yourself" idea. At the present time, we are building over 136,000 square feet of dormitories on the campus by this method. Also, over one hundred of these American L.D.S. carpenters, electricians, masons, plumbers, and painters are deployed over various South Sea Islands with their families, contributing their labor for from two to three years in school construction projects. They supervise and train some five hundred native apprentices who voluntarily donate their labor. This method also provides the local population a sense of ownership in these institutions even though they have little cash to contribute. 


\section{Construction Data}

Architects:

Harold W. Burton \& Douglas W. Burton, associate.

Project cost:

$\$ 251,800.00$ for material costs. 55,000 hours of donated missionary labor valued at $\$ 125,000.00$.

Style of architecture:

Contemporary oriental influence.

Plan:

Designed on a $13^{\prime}-6^{\prime \prime}$ module.

Type of building according to code:

Class "A" type I fireproof structure.

\section{Wall construction:}

Concrete tilt-up wall construction.

\section{Floor construction:}

Earth bearing cement floors on main floor. Steel joist reinforced concrete slab on second story.

\section{Roof construction:}

Steel trusses $13^{\prime}-6^{\prime \prime}$ on center (module).

Roof:

Corrugated asbetos roof.
Windows:

Awning type aluminum.

Exterior doors:

Aluminum frame, glazed lights.

Ornamental trim:

Glass mosaic, ornamental aluminum and wrought iron.

Floor coverings:

Cork tile-rubber cove base.

Lighting:

Tubular fluorescent.

Wood trim:

Philippine wood glazed natural finish.

\section{Furniture:}

Hard rock maple with plastic tops.

Planning:

According to program issued by Kenneth T. Slack, Librarian of the Church College of Hawaii.

Architects fee:

$5 \%$ of the cost.

Total area of the building:

18,500 square feet which includes covered lanai and colonnade.

Storage and Deposit Libraries

(Continued from page 452)

problems, and the knotty difficulties of maintaining bibliographical control of widely scattered resources.

Some research in legal precedents will be required to enable interstate or even intra-state free relocation of library materials, but it seems quite likely that this concept will require new legislation rather than a review of past law. Research will be needed to demonstrate the importance of national responsibility, for this is one area where, with the exception of a few federal libraries, our country has developed very democratically a thoroughly dispersed national responsibility.
The above few indications of directions for research are not to be construed as implying that nothing has been done. However, we must recognize that it is far easier to find subjects needing research in our field, than areas where permanent solutions have been found. ${ }^{17}$ In the literature of storage and deposit libraries, despite its very considerable volume, we find only some germs of ideas, fundamentally sound, but insufficiently developed to obtain general acceptance in practice.

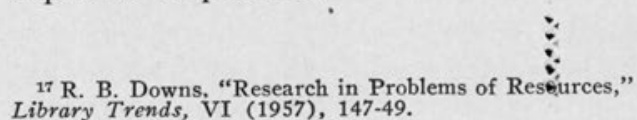

